Article

\title{
Oxidation of Long-Chain $\alpha$-Olefins Using Environmentally-Friendly Oxidants
}

\author{
Kamil Peckh, Dawid Lisicki, Gabriela Talik and Beata Orlińska * \\ Department of Organic Chemical Technology and Petrochemistry, Silesian University of Technology, B. \\ Krzywoustego 4, 44-100 Gliwice, Poland; kamil.peckh@polsl.pl (K.P.); dawid.lisicki@polsl.pl (D.L.); \\ gabriela.talik@polsl.pl (G.T.) \\ * Correspondence: beata.orlinska@polsl.pl
}

Received: 14 September 2020; Accepted: 8 October 2020; Published: 13 October 2020

\begin{abstract}
Studies on the oxidation of $\alpha$-olefins via the two-stage method are presented. The new method consisted of oxidizing $\mathrm{C} 30+\alpha$-olefins with hydrogen peroxide (2 equiv.) and subsequent oxidation with oxygen. Products with high acid numbers (29-82 $\mathrm{mgKOH} / \mathrm{g}$ ) and saponification numbers (64-140 $\mathrm{mgKOH} / \mathrm{g}$ ) were obtained and compared with products obtained using only hydrogen peroxide or oxygen. It was demonstrated that $\mathrm{H}_{2} \mathrm{O}_{2}$ can be partially replaced by oxygen in the oxidative cleavage reaction of $\alpha$-olefins. $N$-hydroxyphthalimide in combination with $\mathrm{Co}(\mathrm{acac})_{2}$ demonstrated high activity in the oxidation stage using oxygen.
\end{abstract}

Keywords: $\alpha$-olefins; oxidation; oxidative cleavage; $N$-hydroxyphthalimide

\section{Introduction}

The oxidative cleavage of alkenes is an important type of reaction in the chemical industry. In such reactions, an oxidizing agent cleaves $\mathrm{C}=\mathrm{C}$ double bonds (Scheme 1 ) to produce two carbonyl-containing compounds (aldehydes and/or ketones). Aldehydes can be further oxidized to corresponding carboxylic acids. These are well-studied reactions, and numerous data has been produced on the use of various oxidants, catalysts, and raw materials. In addition to alkenes, terpenes, oils, fats, and fatty acid derivatives containing double bonds have been used as raw materials [1].

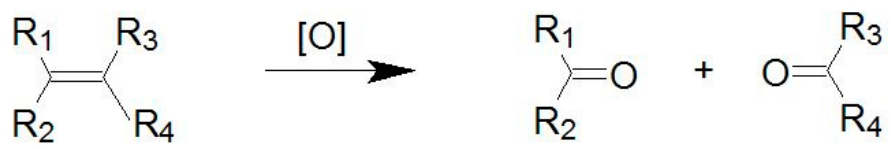

Scheme 1. Oxidative cleavage of olefins.

Various oxidizing agents, including $\mathrm{KMnO}_{4}$ [2,3] and chromium (e.g., $\mathrm{CrO}_{2} \mathrm{Cl}_{2}$ [4]), ruthenium (e.g., $\mathrm{RuO}_{4}$ [5]), and osmium (e.g., $\mathrm{OsO}_{4}$ [6]) oxides have been studied. These oxidants are often used in stoichiometric amounts and combined with other oxidants [1], e.g., $\mathrm{OsO}_{4}$ was used in a mixture with $\mathrm{NaIO}_{4}$ (the so-called Lemieux-Johnson protocol). Unfortunately, ruthenium and osmium are expensive metals, and osmium and chromium are also very toxic, which limits the industrial application of the above-mentioned systems [1]. Oxone [7,8], $\mathrm{PhI}(\mathrm{OAc})_{2}$ [9], $m$-chloroperoxybenzoic acid [10], and tert-butyl hydroperoxide [11-15] have also been used as oxidants. Industrial oxidative cleavage reaction of oleic acid to pelargonic and azelaic acids [1] is carried out using ozone as an oxidizing agent without the addition of a metallic catalyst [16]; however, due to its instability, ozone is hazardous and requires in situ formation, and it also requires specialized equipment, which increases production costs [17]. 
For several years, much attention has been devoted to the use of ecologically-friendly oxidizing agents such as hydrogen peroxide and oxygen in oxidative cleavage reactions [18]. Oxygen is used because of its lower cost, which is particularly important for large-scale processes. Unfortunately, oxygen works well only in case of olefins containing a phenyl ring at the vinyl position, and the use of oxygen often requires specialized or expensive catalytic systems $[19,20]$.

The use of $\mathrm{H}_{2} \mathrm{O}_{2}$ in the oxidative cleavage of aliphatic olefins [21-28] has been widely described. $\mathrm{H}_{2} \mathrm{O}_{2}$ is most often used in combination with metallic catalysts based on selenium [29], palladium [30], rhenium [21], ruthenium [31], iron [22], and especially tungsten [23-27,32-36]. Tungsten-catalyzed reactions proceed through a mechanism that involves epoxidation, epoxide hydrolysis to diol, and subsequent oxidation of the diol to the corresponding aldehyde, which may be subsequently oxidized to a carboxylic acid (Scheme 2). Tungsten was introduced into the system in the form of $\mathrm{H}_{3} \mathrm{PW}_{12} \mathrm{O}_{40}[25,36], \mathrm{Na}_{2} \mathrm{WO}_{4}[24,27,33]$, and most often as $\mathrm{H}_{2} \mathrm{WO}_{4}[28,34,35]$.

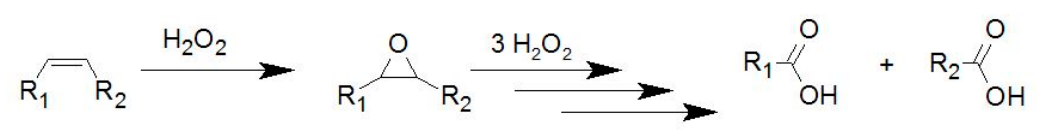

Scheme 2. Tungsten-catalyzed oxidative cleavage reaction of aliphatic olefins using hydrogen peroxide.

When hydrogen peroxide is used, a two-phase system is formed, making it necessary to use a phase-transfer catalyst, which is most often a tetraalkylammonium salt [23-28,32,33,36]. As a result of the interactions between hydrogen peroxide, tungsten compounds, and phase transfer agents, new, more active catalysts are often formed. For example, a catalyst $\left[\mathrm{C}_{5} \mathrm{H}_{5} \mathrm{~N}\left(\mathrm{CH}_{2}\right)_{15} \mathrm{Me}_{3}\left\{\mathrm{PO}_{4}\left[\mathrm{WO}\left(\mathrm{O}_{2}\right)_{2}\right]_{4}\right\}\right.$ was obtained using $\mathrm{H}_{2} \mathrm{O}_{2}, \mathrm{H}_{3} \mathrm{PW}_{12} \mathrm{O}_{40} \cdot 15.4 \cdot \mathrm{H}_{2} \mathrm{O}$, and $\left[\mathrm{C}_{5} \mathrm{H}_{5} \mathrm{~N}\left(n-\mathrm{C}_{16} \mathrm{H}_{33}\right)\right][\mathrm{Cl}]$ to oxidatively cleave oleic acid [32]. After $1 \mathrm{~h}$ of reaction at $80^{\circ} \mathrm{C}$, azelaic and pelargonic acids were obtained in yields of $86 \%$ and $82 \%$, respectively.

Undoubtedly, the advantages of using $\mathrm{H}_{2} \mathrm{O}_{2}$ as an oxidant are the formation of water as a by-product and the high content of active oxygen (47 wt.\%) [37]. Disadvantages include the introduction of large amounts of water into the system due to its concentration-in the range of 30-60\%. In addition, according to the reaction stoichiometry, it is necessary to use 4 equiv. of $\mathrm{H}_{2} \mathrm{O}_{2}$, and in the processes described in the literature, $\mathrm{H}_{2} \mathrm{O}_{2}$ is often used in stoichiometric excess. For example, as much as $325 \mathrm{mmol}$ of $\mathrm{H}_{2} \mathrm{O}_{2}$ per $65 \mathrm{mmol}$ of raw material was used in the oxidation of oleic acid, which is 5 equiv. of this oxidant [36].

According to the limited literature data, hydrogen peroxide can be partially replaced in this process with cheaper and abundant oxygen. Hydrogen peroxide is necessary for the epoxidation of carbon-carbon double bonds, while oxygen can be used in subsequent oxidation stages of formed diol by epoxide hydrolysis. So far, such a solution has been reported for the oxidation of oleic acid to azelaic and pelargonic acids (Scheme 3) [38-40].

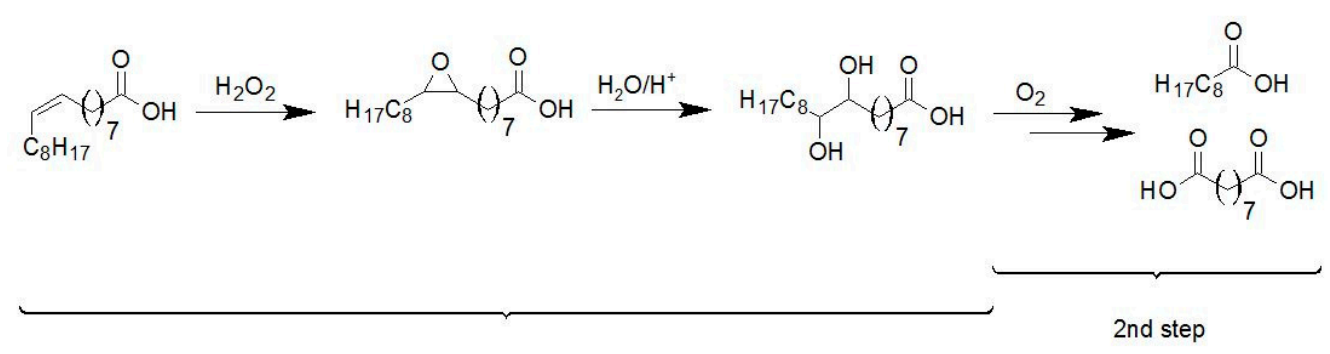

1 st step

Scheme 3. Two-step oxidative cleavage of oleic acid. 
The reported processes involve epoxidation catalyzed by $\mathrm{H}_{2} \mathrm{WO}_{4}$ followed by hydrolysis to a diol [38-40]. In the second stage, in situ formed catalysts composed of $\mathrm{H}_{2} \mathrm{WO}_{4}$ and $\mathrm{Co}(\mathrm{OAc})_{2}$ or polyoxometalates such as $\mathrm{H}_{6} \mathrm{CoW}_{12} \mathrm{O}_{40}$ and $\left(\mathrm{NH}_{4}\right)_{8}\left[\mathrm{Co}_{2} \mathrm{~W}_{12} \mathrm{O}_{42}\right][38,39]$ as well as $\mathrm{Co}(\mathrm{acac})_{3}$ in combination with $\mathrm{N}$-hydroxyphthalimide (NHPI) have used [40]. Oakley [40] introduced the catalysts $\mathrm{NHPI} / \mathrm{Co}(\mathrm{III})$ directly into the product of the first stage obtained by oxidation of oleic acid by $\mathrm{H} 2 \mathrm{O} 2$ (only $1.2 \mathrm{mmol} \mathrm{H} 2 \mathrm{O} 2 / \mathrm{mol} \mathrm{C}=\mathrm{C}$ ) in the presence of $\mathrm{H} 2 \mathrm{WO} 4$ in tert-butanol at reflux (2 h). Aerobic oxidation was carried out for $3 \mathrm{~h}$ at $70-75{ }^{\circ} \mathrm{C}$, which produced azelaic and pelargonic acids in $15 \%$ yield. Higher yields were obtained when methyl erucate was used as the raw material, and brassylic and pelargonic acids were obtained in $41 \%$ and $54 \%$ yields, respectively.

The high catalytic activity of NHPI has been demonstrated in many free-radical oxidation reactions using oxygen, including the aerobic cleavage of alkenes. $\alpha$-Methylstyrene and its derivatives were oxidized to acetophenones by oxygen in the presence of NHPI combined with cobalt(II) compounds, azo compounds, or alkylammonium salts [41]. Unfortunately, the cleavage of double bonds of non-aromatic alkenes, such as 1-cyclohexene or 1-dodecene, did not occur.

Herein, we describe the oxidation of long-chain $\alpha$-olefins (C30+), consisting of subsequent oxidation by hydrogen peroxide and oxygen. We have recently described the oxidative cleavage of $\mathrm{C} 30+$ alkenes using 5 equiv. of $\mathrm{H}_{2} \mathrm{O}_{2}$ and catalyst composed of $\mathrm{H}_{2} \mathrm{WO}_{4}$, Luviquat as PTC and $\mathrm{H}_{2} \mathrm{SO}_{4}$ at $90^{\circ} \mathrm{C}$ [28]. This paper investigates the possibility of partially replacing $\mathrm{H}_{2} \mathrm{O}_{2}$ with cheaper oxygen in this process. To the best of our knowledge, such a two-stage oxidation process for long-chain, linear $\alpha$-olefins has not yet been described. Long-chain olefins were obtained as a product of ethylene oligomerization, thermal cracking of paraffins, or polyethylenes. The significance of the latter method may be higher due to the possibility of using post-consumer polyethylene as a raw material. Polar products obtained by the oxidation of long-chain olefins containing carboxyl and ester groups can be used to produce surfactants, plasticizers, waxes, lubricants, greases, and adhesives.

\section{Materials and Methods}

\subsection{Materials}

Alpha Plus C30+ olefins (Chevron-Phillips, Diegem, Belgium), hydrogen peroxide (30 or $50 \mathrm{wt} . \%$ in water, Acros Organics), tungstic acid (Fluka), cetyldimethyl(2-hydroxyethyl)ammonium dihydrogen phosphate (Luviquat, 30\% in water, Aldrich, Steinheim, Germany), N-hydroxyphthalimide (NHPI, Sigma-Aldrich, Steinheim, Germany), Co(acac) 2 (Sigma-Aldrich), and methylcyclohexane $(\mathrm{MCH}$, Alfa Aesar, Karlsruhe, Germany) were commercially available and used without purification.

\section{2. $\mathrm{C} 30+$ Olefins Oxidation Using $\mathrm{H}_{2} \mathrm{O}_{2}$}

$\mathrm{C} 30+\alpha$-olefin (40 or $200 \mathrm{~g}), \mathrm{H}_{2} \mathrm{WO}_{4}\left(0.75-3.0\right.$ wt.\%), Luviquat (0.75-5.0 wt.\%), $0.5 \mathrm{M} \mathrm{H}_{3} \mathrm{PO}_{4}$ or $0.5 \mathrm{M} \mathrm{H}_{2} \mathrm{SO}_{4}\left(0-0.1 \mathrm{~cm}^{3}\right)$, and (optional) methylcyclohexane as diluent were placed in a round bottom flask equipped with a mechanical stirrer (300-400 rpm) and heated to $70^{\circ} \mathrm{C}$. Next, hydrogen peroxide ( 30 or $50 \mathrm{wt} . \%$ ) was dropped $\left(2 \mathrm{~g} / \mathrm{min}\right.$ ), and the mixture was heated to $85^{\circ} \mathrm{C}$. The reaction was conducted at $85^{\circ} \mathrm{C}$ for $2-10 \mathrm{~h}$. Products were purified by washing once at $80-90^{\circ} \mathrm{C}$ with distilled water $\left(100\right.$ or $500 \mathrm{~mL}$, resp.) and dried at $80^{\circ} \mathrm{C}$. Next, acid numbers (AN) and saponification numbers (SN) of products were determined.

\subsection{C30+ Olefins Oxidation Using $\mathrm{H}_{2} \mathrm{O}_{2}$ and $\mathrm{O}_{2}$}

$\mathrm{C} 30+\alpha$-olefin $(40$ or $200 \mathrm{~g}$ ) were oxidized using hydrogen peroxide, purified by washing with water and dried according to the described above method. The obtained product $(15 \mathrm{~g}), \mathrm{Co}(\mathrm{acac})_{2}$ (0.1-1 wt.\%), and/or NHPI (1 wt.\%) were introduced into a $100 \mathrm{~mL}$ reactor (Autoclave Engineers Inc., Clevelend, $\mathrm{OH}, \mathrm{USA}$ ) made of Hastelloy C-276 steel and equipped with a mechanical stirrer, heating jacket, temperature and pressure sensors, and reflux condenser. The mixture was heated to $90{ }^{\circ} \mathrm{C}$ to melt the wax, then the reactor was sealed and filled with oxygen up to a pressure of $0.5 \mathrm{MPa}$ and then 
heated up to reaction temperature. The reaction was carried out at $90-110{ }^{\circ} \mathrm{C}$ for $2.5-7.5 \mathrm{~h}$ at $1000 \mathrm{rpm}$. The AN and SN of the obtained product were determined.

The reaction at atmospheric pressure using an oxygen flow rate of $3 \mathrm{~L} / \mathrm{h}$ was also carried out in the above-described autoclave $\left(100{ }^{\circ} \mathrm{C}, 0.1 \mathrm{MPa}, 5 \mathrm{~h}, 1000 \mathrm{rpm}\right)$.

\section{4. $\mathrm{C} 30+$ Olefins Oxidation Using $\mathrm{O}_{2}$}

$\mathrm{C} 30+\alpha$-olefin (15 g), Co(acac) $)_{2}(0.1 \mathrm{wt} . \%)$ and/or NHPI (1 wt.\%) were introduced into a $100 \mathrm{~mL}$ above-described reactor (Autoclave Engineers Inc., USA) and oxidized under an oxygen pressure of $0.5 \mathrm{MPa}$ at $100{ }^{\circ} \mathrm{C}$ for $5 \mathrm{~h}$ at $1000 \mathrm{rpm}$, as described above. The AN and SN of the obtained product were determined.

\subsection{Double-Bond Content Calculation}

The double-bond content in the starting material and obtained products was calculated based on ${ }^{1} \mathrm{H}$ NMR spectroscopy (Agilent, Palo Alto, CA, USA). Sample (0.01-0.02 g) and naphthalene (0.001-0.002 g) as an internal standard were dissolved in $\mathrm{CDCl}_{3}$ and introduced into NMR tube. The ratio of the number of double-bond to the number of naphthalene molecules was calculated by integration of the peak areas corresponding to the respective functional groups.

\subsection{Acid Number}

A sample (ca. $0.3 \mathrm{~g}$ ) of the products and mixture of $25 \mathrm{~mL}$ of xylene with 2-methyl-2,4-pentanediol $(2: 1 \mathrm{v} / \mathrm{v})$ were placed in a conical flask equipped with a condenser. The mixture was heated to obtain a clear solution. Next, the hot mixture was titrated with $0.05 \mathrm{M} \mathrm{KOH}$ in ethanol using phenolphthalein as an indicator. The acid number (AN) is the mass of $\mathrm{KOH}$ (in $\mathrm{mg}$ ) required to neutralize the carboxylic acid groups in $1 \mathrm{~g}$ of sample.

\subsection{Saponification Number}

A sample (ca. $1 \mathrm{~g}$ ) of the product, a mixture of $25 \mathrm{~mL}$ of xylene with 1-propanol (4:1 v/v) and $25 \mathrm{~mL}$ of $0.1 \mathrm{M} \mathrm{KOH}$ in ethanol were placed in a conical flask. The mixture was heated under reflux for $30 \mathrm{~min}$. Next, the hot mixture was titrated with $0.1 \mathrm{M} \mathrm{HCl}$ using phenolphthalein as an indicator. In a blank test, the same mixture but without the sample was used. The saponification number (SN) is the mass of $\mathrm{KOH}$ (in $\mathrm{mg}$ ) required to neutralize the free carboxylic groups and esters in $1 \mathrm{~g}$ of sample.

\subsection{Viscosity Determination}

Dynamic viscosity was determined using Brookfield Rheometer (Brookfield Inc., Toronto, ON, Canada). A sample (ca. $2.5 \mathrm{~g}$ ) of the product was put on a measuring plate heated with circulating oil at a set temperature of $120^{\circ} \mathrm{C}$. Then, the measurements were performed using five preset shear rates $\left(200-4000 \mathrm{~s}^{-1}\right)$. The dynamic viscosity of products and raw material was constant in the given range of shear rates, showing that they behaved as Newtonian fluids.

\subsection{Apparatus}

The following apparatus were used in this study: a gas chromatograph (GC, Agilent Technologies 7890C, (Agilent, Palo Alto, CA, USA) equipped with a ZB 5HT column $(30 \mathrm{~m} \times 0.25 \mathrm{~mm} \times 0.25 \mu \mathrm{m})$ connected to a mass spectrometer (MS, Agilent Technologies 5975C; EI $70 \mathrm{eV}$ ); an EZ-Melt MPA120 automated melting point apparatus with digital image processing software (Stanford Research Systems, Sunnyvale, CA, USA); Brookfield RST CPS Rheometer (Brookfield Inc., Toronto, ON, Canada) with RCT-75-1 and RCT-25-2 and Rheo3000 software; an FT-IR Mettler-Toledo iC10 spectrometer (Mettler-Toledo, Columbus, OH, USA) equipped with an ATR probe; an Agilent 400 NMR spectrometer operating at $400 \mathrm{MHz}$. 


\section{Results and Discussion}

Studies on the oxidation of $\alpha$-olefins via a two-stage method were carried out. The method consisted of oxidizing the raw material with hydrogen peroxide (first stage) and subsequent oxidation of the product with oxygen (second stage). For comparison, olefins were also oxidized using only $\mathrm{H}_{2} \mathrm{O}_{2}$ or oxygen. Commercially-available $\mathrm{C} 30+$ olefins were used as the starting material $(\mathrm{C} 30+)$. According to the producer (Chevron-Phillips), they contain $71.4 \mathrm{wt} . \%$ of linear and $24.7 \mathrm{wt} . \%$ of branched $\alpha$-olefins. GC-MS analysis showed that the C $30+$ olefins is a mixture of olefins containing an even number of carbon atoms (mostly C28 to C42) (Figure 1) [28]. Based on the surface areas, the amount of hydrocarbons in the raw material increased in the following order: $\mathrm{C} 30>\mathrm{C} 32>\mathrm{C} 28$ $>\mathrm{C} 34>\mathrm{C} 36>\mathrm{C} 38>\mathrm{C} 40>\mathrm{C} 42$. The double bond content in C30+ olefins determined based on ${ }^{1} \mathrm{H}$ NMR spectroscopy was $2.030 \mathrm{mmol} \mathrm{C}=\mathrm{C} / \mathrm{g}$, corresponding to the theoretical bromine number of $32.44 \mathrm{~g} \mathrm{Br}_{2} / 100 \mathrm{~g}$ ) (Figure 2). The viscosity of $\mathrm{C} 30+$ was $3.7 \mathrm{mPa} \cdot \mathrm{s}\left(\right.$ at $120^{\circ} \mathrm{C}$ ), and the melting point was in the range of $59.6-69.6^{\circ} \mathrm{C}$. The oxidation degree of obtained products was established based on the content of carboxyl and ester groups by determining their acid number (AN) and saponification number (SN). For selected products, their viscosity, double bond content, and composition using GC-MS were also determined.

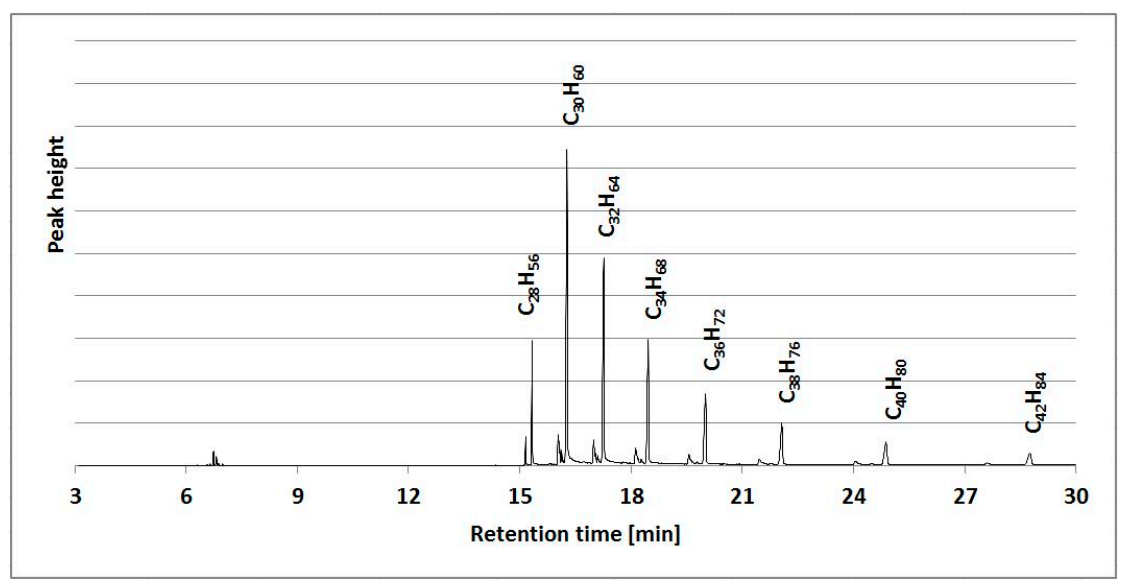

Figure 1. GC-MS chromatogram of starting material C30+ olefins (mass spectra Figures S1-S8).

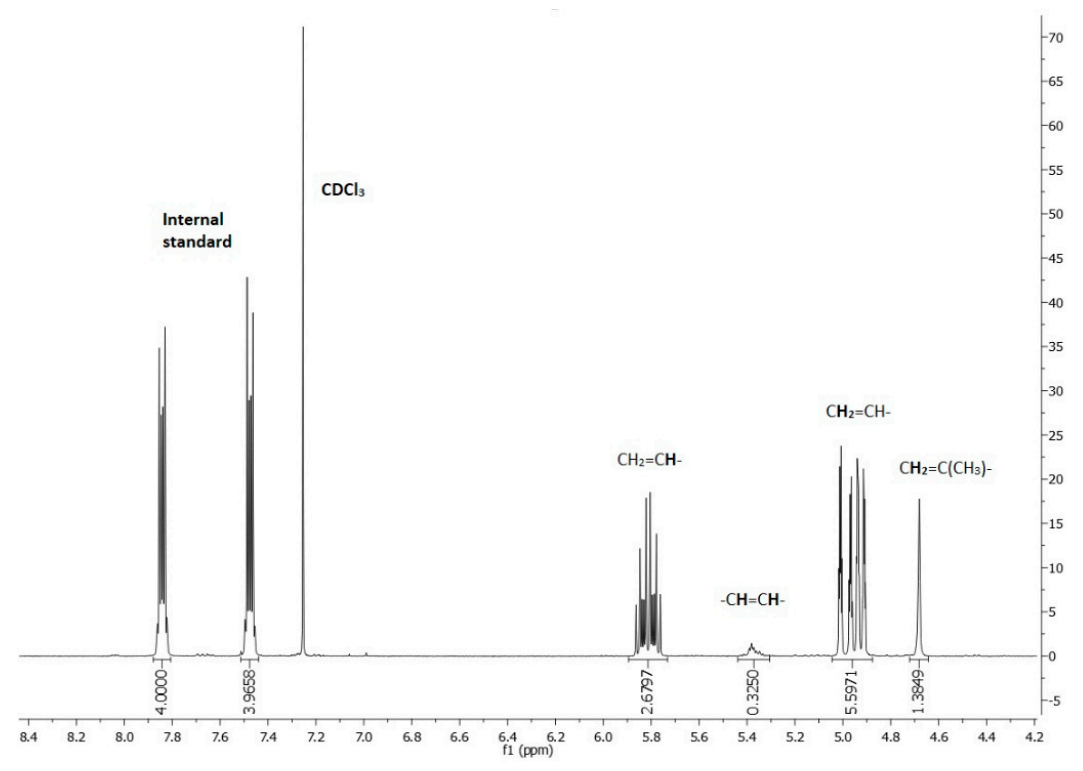

Figure 2. ${ }^{1} \mathrm{H}$ NMR spectrum of starting material C $30+$ olefins. 


\subsection{First Stage: Oxidation of C30+ Olefins Using $\mathrm{H}_{2} \mathrm{O}_{2}$}

Based on our previous work [28], the catalyst system composed of $\mathrm{H}_{2} \mathrm{WO}_{4}$, a halogen-free lipophilic PTC, i.e. cetyldimethyl(2-hydroxyethyl)ammonium dihydrogen phosphate (Luviquat), and $\mathrm{H}_{2} \mathrm{SO}_{4}$ or $\mathrm{H}_{3} \mathrm{PO}_{4}$ was chosen for oxidation stage with hydrogen peroxide. The reaction temperature was limited by the thermal stability of hydrogen peroxide and also by the melting point of the raw material and product $\left(85^{\circ} \mathrm{C}\right)$.

The effects of the amount and concentration of hydrogen peroxide, the amount of catalysts, reaction time, and the addition of solvent on the oxidation of $\mathrm{C} 30+$ olefins were established in the presented studies.

\subsubsection{Effect of the Amount and Concentration of $\mathrm{H}_{2} \mathrm{O}_{2}$}

The results of the effect of 30 or $50 \% \mathrm{H}_{2} \mathrm{O}_{2}$ on the $\mathrm{C} 30+$ olefins oxidation are presented in Table 1 . Hydrogen peroxide in amount of 1,2,3, and 4 equiv. was used. The reactions were carried out without solvent, as well as in methylcyclohexane, against $\mathrm{H}_{2} \mathrm{WO}_{4}(1.5$ or $3 \%)$, Luviquat (2.5 or $\left.5 \%\right)$, and $\mathrm{H}_{2} \mathrm{SO}_{4}$, at $85^{\circ} \mathrm{C}$ for $10 \mathrm{~h}$.

Table 1. Effect of amount and concentration of $\mathrm{H}_{2} \mathrm{O}_{2}$ on the $\mathrm{C} 30+$ olefins oxidation.

\begin{tabular}{|c|c|c|c|c|c|c|c|c|}
\hline Entry & $\begin{array}{c}\text { Equiv. } \\
\text { of } \mathrm{H}_{2} \mathrm{O}_{2}\end{array}$ & $\begin{array}{c}\mathrm{H}_{2} \mathrm{O}_{2} \\
\%\end{array}$ & $\begin{array}{c}\mathrm{AN}, \\
\mathrm{mg} \mathrm{KOH} / \mathrm{g}\end{array}$ & $\begin{array}{c}\mathrm{SN}, \\
\mathrm{mg} \mathrm{KOH} / \mathrm{g}\end{array}$ & $\begin{array}{c}\mathrm{EN}{ }^{*}, \\
\mathrm{mg} \mathrm{KOH} / \mathrm{g}\end{array}$ & $\begin{array}{c}\mathrm{C}=\mathrm{C}, \\
\mathrm{mmol} / \mathrm{g}\end{array}$ & $\begin{array}{c}\text { Conversion, } \\
\% \\
\end{array}$ & $\begin{array}{c}\text { Viscosity at } 120^{\circ} \mathrm{C} \\
\mathrm{mPa} \cdot \mathrm{s}\end{array}$ \\
\hline 1 & 1 & 50 & 16 & 22 & 6 & 0.782 & 61 & 9.7 \\
\hline 3 & 3 & 50 & 25 & 45 & 20 & 0.058 & 97 & 10.2 \\
\hline 4 & 4 & 50 & 37 & 57 & 20 & 0.033 & 98 & 13.4 \\
\hline $5^{a}$ & 1 & 50 & 12 & 15 & 3 & 0.782 & 61 & 7.1 \\
\hline $8^{a}$ & 4 & 50 & 33 & 49 & 16 & 0.080 & 96 & 14.2 \\
\hline $9^{a}$ & 1 & 30 & 10 & 21 & 11 & 0.656 & 68 & 9.1 \\
\hline $10^{a}$ & 2 & 30 & 15 & 26 & 11 & 0.332 & 84 & 11.7 \\
\hline $11^{\mathrm{a}}$ & 3 & 30 & 25 & 43 & 18 & 0.108 & 95 & 13.4 \\
\hline $12^{\mathrm{a}}$ & 4 & 30 & 18 & 31 & 13 & 0.207 & 90 & 7.6 \\
\hline
\end{tabular}

Note: Olefins $\mathrm{C} 30+40 \mathrm{~g}, \mathrm{H}_{2} \mathrm{O}_{2} 50$ or $30 \%, \mathrm{H}_{2} \mathrm{WO}_{4} 3$ wt. $\%$, Luviquat $5 \mathrm{wt} . \%, \mathrm{H}_{2} \mathrm{SO}_{4} 0.5 \mathrm{M} 0.1 \mathrm{~mL}, 85{ }^{\circ} \mathrm{C}, 10 \mathrm{~h}$, $400 \mathrm{rpm},{ }^{\mathrm{a}} \mathrm{H}_{2} \mathrm{WO}_{4} 1.5 \mathrm{wt} . \%$, Luviquat $2.5 \mathrm{wt} . \%$, b solvent $32 \mathrm{~g}$, $300 \mathrm{rpm} .{ }^{*}{ }^{*} \mathrm{EN}$-Ester number.

The results showed that increasing the amount of hydrogen peroxide oxidant from 1 to 4 equiv. decreased the number of double bonds in the products. According to the reaction stoichiometry, 1 equiv. of $\mathrm{H}_{2} \mathrm{O}_{2}$ is sufficient for the complete epoxidation of the $\mathrm{C}=\mathrm{C}$ double bond. However, in our study, using 1 equiv. of $\mathrm{H}_{2} \mathrm{O}_{2}$ resulted in the incomplete conversion of $\mathrm{C}=\mathrm{C}$ bonds. For example, the conversion was $61 \%$ (Table 1, Entry 1) or 55\% (Table 1, Entry 13) in a reaction carried out without solvent and in $\mathrm{MCH}$, respectively. This occurred because hydrogen peroxide was consumed in the subsequent oxidation of diols to carboxylic acids, and also because it partially decomposed during the reaction. A two-fold increase in the $\mathrm{H}_{2} \mathrm{O}_{2}$ amount significantly increased the conversion of $\mathrm{C}=\mathrm{C}$ bonds to 89 and $80 \%$, respectively (Table 1, Entries 2 and 14). The use of $\mathrm{H}_{2} \mathrm{O}_{2}$ at both concentrations, 30 and $50 \%$, provided comparable conversions of $\mathrm{C}=\mathrm{C}$ bonds. For example, when 2 equiv. of 30 or $50 \% \mathrm{H}_{2} \mathrm{O}_{2}$ were used, the conversions reached 84 and 89\%, respectively. (Table 1, Entries 10 and 2). The use of $30 \% \mathrm{H}_{2} \mathrm{O}_{2}$ is cheaper and safer to use, but it introduces excess water into the system.

It was demonstrated that the addition of $\mathrm{MCH}$ only slightly reduced the conversion of $\mathrm{C}=\mathrm{C}$ bonds (at 2 equiv. $\mathrm{H}_{2} \mathrm{O}_{2}$, conversion decreased from 89 to $80 \%$ ), while it reduced the reaction mixture viscosity, which facilitated heat removal and thus improved process safety; however, the use of $\mathrm{MCH}$ requires additional product purification steps. 
In the oxidation of olefins with hydrogen peroxide, an epoxide is first formed, which is then hydrolyzed to the respective diol. In the subsequent reactions, the diol is oxidized to corresponding carboxylic acids, which can form esters with these diols. As expected, the content of carboxylic acids and respective esters in the reaction products increased with the amount of hydrogen peroxide. It was also observed that the product viscosity slightly increased with the oxidation degree.

\subsubsection{Effect of Amount of Catalysts}

The effect of $\mathrm{H}_{2} \mathrm{WO}_{4}$, Luviquat (Table 2), and $\mathrm{H}_{2} \mathrm{SO}_{4}$ or $\mathrm{H}_{3} \mathrm{PO}_{4}$ (Table 3) on the oxidation of C30+ olefins with hydrogen peroxide was investigated. Reactions were carried out at $85^{\circ} \mathrm{C}$ without solvent for $10 \mathrm{~h}$.

Table 2. Effect of $\mathrm{H}_{2} \mathrm{WO}_{4}$ and Luviquat on the $\mathrm{C} 30+$ olefins oxidation using $\mathrm{H}_{2} \mathrm{O}_{2}$.

\begin{tabular}{|c|c|c|c|c|c|c|c|c|}
\hline Entry & $\begin{array}{l}\text { Luviquat, } \\
\text { wt. } \%\end{array}$ & $\begin{array}{c}\mathrm{H}_{2} \mathrm{WO}_{4} \\
\text { wt. } \%\end{array}$ & $\begin{array}{c}\mathrm{AN}, \\
\mathrm{mg} \mathrm{KOH} / \mathrm{g}\end{array}$ & $\begin{array}{c}\mathrm{SN}, \\
\mathrm{mg} \mathrm{KOH} / \mathrm{g}\end{array}$ & $\begin{array}{c}\text { EN, } \\
\mathrm{mg} \mathrm{KOH} / \mathrm{g}\end{array}$ & $\begin{array}{c}\mathrm{C}=\mathrm{C}, \\
\mathrm{mmol} / \mathrm{g}\end{array}$ & $\begin{array}{c}\text { Conversion, } \\
\%\end{array}$ & $\begin{array}{c}\text { Viscosity at } 120^{\circ} \mathrm{C}, \\
\mathrm{mPa} \cdot \mathrm{s}\end{array}$ \\
\hline 1 & - & - & 5 & 11 & 6 & 1.816 & 11 & 3.5 \\
\hline 2 & - & 1.5 & 4 & 8 & 4 & 0.879 & 57 & 7.1 \\
\hline 3 & 2.5 & - & 9 & 25 & 16 & 1.344 & 34 & 4.9 \\
\hline 4 & 5.0 & - & 6 & 5 & 1 & 1.927 & 5 & 3.7 \\
\hline 5 & 0.75 & 1.5 & 16 & 26 & 10 & 0.236 & 88 & 4.9 \\
\hline 8 & 5.0 & 1.5 & 26 & 40 & 14 & 0.050 & 98 & 10.0 \\
\hline 9 & 2.5 & 0.75 & 21 & 42 & 21 & 0.227 & 89 & 6.6 \\
\hline 10 & 5.0 & 3.0 & 25 & 45 & 20 & 0.058 & 97 & 10.2 \\
\hline
\end{tabular}

Note: Olefins $\mathrm{C} 30+40 \mathrm{~g}$, 3 equiv. of $\mathrm{H}_{2} \mathrm{O}_{2} 50 \%, \mathrm{H}_{2} \mathrm{SO}_{4} 0.5 \mathrm{M} 0.1 \mathrm{~mL}, 85^{\circ} \mathrm{C}, 10 \mathrm{~h}, 400 \mathrm{rpm}$.

Table 3. Effect of $\mathrm{H}_{2} \mathrm{SO}_{4}$ or $\mathrm{H}_{3} \mathrm{PO}_{4}$ on the $\mathrm{C} 30+$ olefins oxidation using $\mathrm{H}_{2} \mathrm{O}_{2}$.

\begin{tabular}{|c|c|c|c|c|c|c|c|}
\hline Entry. & $\begin{array}{c}\text { Acid } 0.5 \mathrm{M}, \\
\mathrm{mL}\end{array}$ & $\begin{array}{c}\mathrm{AN}, \\
\mathrm{mg} \mathrm{KOH} / \mathrm{g}\end{array}$ & $\begin{array}{c}\mathrm{SN}, \\
\mathrm{mg} \mathrm{KOH} / \mathrm{g}\end{array}$ & $\begin{array}{c}\text { EN, } \\
\mathrm{mg} \mathrm{KOH} / \mathrm{g}\end{array}$ & $\begin{array}{c}\mathrm{C}=\mathrm{C}, \\
\mathrm{mmol} / \mathrm{g}\end{array}$ & $\begin{array}{c}\text { Conversion, } \\
\%\end{array}$ & $\begin{array}{c}\text { Viscosity at } 120^{\circ} \mathrm{C} \\
\mathrm{mPa} \cdot \mathrm{s}\end{array}$ \\
\hline $1^{\mathrm{a}}$ & - & 15 & 27 & 12 & 0.205 & 90 & 8.5 \\
\hline $2^{\mathrm{a}}$ & 0.1 & 18 & 39 & 21 & 0.195 & 90 & 14.9 \\
\hline $3^{a}$ & 1 & 10 & 28 & 18 & 0.237 & 88 & 8.5 \\
\hline $4^{b}$ & 0.1 & 22 & 39 & 17 & 0.233 & 89 & 12.6 \\
\hline $5^{b}$ & 1 & 17 & 32 & 15 & 0.229 & 89 & 15.6 \\
\hline
\end{tabular}

${ }^{\mathrm{b}} \mathrm{H}_{3} \mathrm{PO}_{4}$.

The results showed that to obtain a low content of double bonds, it is helpful to use a combination of $\mathrm{H}_{2} \mathrm{WO}_{4}$ and Luviquat (Table 2, Entries 1, 2, 7). Increasing the Luviquat content from 0.75 to $2.5 \%$ (Table 2, Entries 5-7) increased the double bond conversion and increased the amount of acids and esters in the products. This, in turn, increased the viscosity of the product. When the amount of $\mathrm{H}_{2} \mathrm{WO}_{4}$ increased from 0.75 to $1.5 \%$, the conversion of $\mathrm{C}=\mathrm{C}$ bonds also increased, as did the viscosity of the products (Table 2, Entries 7 and 9).

The addition of $\mathrm{H}_{2} \mathrm{SO}_{4}$ or $\mathrm{H}_{3} \mathrm{PO}_{4}$ to the studied system did not affect the double bond conversion, but it increased the content of acids and esters in the products (Table 3). This probably occurred because of their effect on the hydrolysis of the epoxide to a diol, which underwent subsequent oxidation and esterification.

\subsubsection{Effect of Time of Reaction}

The effect of the reaction time (2-10 h) on the oxidation of C30+ olefins by hydrogen peroxide (2 equiv.) under solvent-free conditions or in $\mathrm{MCH}$ as solvent was studied (Table 4). 
Table 4. Effect of reaction time on the $\mathrm{C} 30+$ olefins oxidation using $\mathrm{H}_{2} \mathrm{O}_{2}$.

\begin{tabular}{|c|c|c|c|c|c|c|c|c|c|}
\hline Entry. & $\begin{array}{l}\text { Luviquat, } \\
\text { wt. } \%\end{array}$ & $\begin{array}{c}\mathrm{H}_{2} \mathrm{WO}_{4}, \\
\text { wt. } \%\end{array}$ & Time, $\mathrm{h}$ & $\begin{array}{c}\text { AN, } \\
\mathrm{mg} \mathrm{KOH} / \mathrm{g}\end{array}$ & $\begin{array}{c}\mathrm{SN}, \\
\mathrm{mg} \mathrm{KOH} / \mathrm{g}\end{array}$ & $\begin{array}{c}\text { EN, } \\
\mathrm{mg} \mathrm{KOH} / \mathrm{g}\end{array}$ & $\begin{array}{c}\mathrm{C}=\mathrm{C}, \\
\mathrm{mmol} / \mathrm{g}\end{array}$ & $\begin{array}{c}\text { Conversion, } \\
\%\end{array}$ & $\begin{array}{c}\text { Viscosity at } 120^{\circ} \mathrm{C}, \\
\mathrm{mPa} \cdot \mathrm{s}\end{array}$ \\
\hline 1 & 0.75 & 0.75 & 2 & 12 & 23 & 11 & 0.333 & 84 & 11.7 \\
\hline 2 & 0.75 & 0.75 & 4 & 14 & 27 & 13 & 0.247 & 88 & 11.6 \\
\hline 4 & 0.75 & 1.5 & 4 & 14 & 28 & 14 & 0.506 & 75 & 10.5 \\
\hline 5 & 1.5 & 0.75 & 2 & 18 & 32 & 14 & 0.207 & 90 & 11.5 \\
\hline 8 & 1.5 & 1.5 & 4 & 16 & 36 & 20 & 0.254 & 87 & 12.1 \\
\hline 9 & 2.5 & 1.5 & 2 & 16 & 30 & 14 & 0.178 & 91 & 11.9 \\
\hline 10 & 2.5 & 1.5 & 4 & 20 & 31 & 11 & 0.227 & 89 & 9.2 \\
\hline 11 & 2.5 & 1.5 & 6 & 17 & 30 & 13 & 0.201 & 90 & 9.1 \\
\hline 12 & 2.5 & 1.5 & 8 & 21 & 35 & 14 & 0.145 & 93 & 8.2 \\
\hline 13 & 2.5 & 1.5 & 10 & 18 & 39 & 21 & 0.195 & 90 & 14.9 \\
\hline
\end{tabular}

Note: Olefins $\mathrm{C} 30+40 \mathrm{~g}, \mathrm{H}_{2} \mathrm{O}_{2} 50 \%$ - 2 equiv., $\mathrm{H}_{2} \mathrm{SO}_{4} 0.5 \mathrm{M} 0.1 \mathrm{~mL}, 85^{\circ} \mathrm{C}, 10 \mathrm{~h}, 400 \mathrm{rpm}$.

When the reaction was carried out with 2 equiv. of $\mathrm{H}_{2} \mathrm{O}_{2}$, significant $\mathrm{C}=\mathrm{C}$ bond conversion was obtained just after $2 \mathrm{~h}$ (e.g., against 2.5\% Luviquat and 1.5\% $\mathrm{H}_{2} \mathrm{WO}_{4}$, it was 91\%). Prolonging the reaction time only slightly increased the ester number.

\subsection{Second Stage: Oxidation Using $\mathrm{O}_{2}$}

A system composed of NHPI and $\mathrm{Co}(\mathrm{acac})_{2}$, known for its high activity for hydrocarbon oxidation with oxygen, was chosen as catalysts for this oxidation step. To determine the effects of catalyst and reaction conditions, we used $\mathrm{C} 30+$ olefins pre-oxidized with hydrogen peroxide as the raw material. Its properties are given in Table 5 .

Table 5. Properties of pre-oxidized with $\mathrm{H}_{2} \mathrm{O}_{2}$ raw material used in the oxidation reaction using oxygen.

\begin{tabular}{|c|c|c|c|c|c|c|c|}
\hline Entry. & $\begin{array}{l}\text { Melting point, } \\
{ }^{\circ} \mathrm{C}\end{array}$ & $\begin{array}{c}\mathrm{AN}, \\
\mathrm{mg} \mathrm{KOH} / \mathrm{g}\end{array}$ & $\begin{array}{c}\mathrm{SN}, \\
\mathrm{mg} \mathrm{KOH} / \mathrm{g}\end{array}$ & $\begin{array}{c}\text { EN, } \\
\mathrm{mg} \mathrm{KOH} / \mathrm{g}\end{array}$ & $\begin{array}{c}\mathrm{C}=\mathrm{C}, \\
\mathrm{mmol} / \mathrm{g}\end{array}$ & $\begin{array}{c}\text { Conversion, } \\
\%\end{array}$ & $\begin{array}{c}\text { Viscosity at } 120^{\circ} \mathrm{C}, \\
\mathrm{mPa} \cdot \mathrm{s}\end{array}$ \\
\hline 1 & $85.1-91.0$ & 31 & 50 & 19 & 0.030 & 99 & 13.1 \\
\hline
\end{tabular}

\subsubsection{Effect of Catalyst}

In Table 6 , the products obtained by oxidation with oxygen catalyzed by $\mathrm{Co}(\mathrm{acac})_{2}$, NHPI, or NHPI/ $\mathrm{Co}(\mathrm{acac})_{2}$ system are compared.

Table 6. Effect of catalyst on the oxidation of the pre-oxidized raw material using oxygen.

\begin{tabular}{ccccccc}
\hline Entry. & Catalyst & $\begin{array}{c}\text { Melting } \\
\text { Point, }{ }^{\circ} \mathbf{C}\end{array}$ & $\begin{array}{c}\text { AN, } \\
\text { mgKOH/gL }\end{array}$ & $\begin{array}{c}\text { SN, } \\
\mathbf{m g K O H} / \mathbf{g}\end{array}$ & $\begin{array}{c}\mathbf{E N} \\
\mathbf{m g K O H} / \mathbf{g}\end{array}$ & $\begin{array}{c}\text { Viscosity at } \mathbf{1 2 0}{ }^{\circ} \mathbf{C}, \\
\mathbf{m P a} \cdot \mathbf{s}\end{array}$ \\
\hline 1 & - & $81.0-87.9$ & 27 & 45 & 18 & 14.1 \\
2 & $\mathrm{Co}(\mathrm{II})$ & $74.3-85.7$ & 55 & 111 & 56 & 16.3 \\
3 & $\mathrm{NHPI}$ & $77.6-90.5$ & 42 & 66 & 24 & 16.1 \\
$4^{\mathrm{a}}$ & $\mathrm{Co}(\mathrm{II}) / \mathrm{NHPI}$ & $70.9-86.1$ & 42 & 95 & 53 & 14.3 \\
5 & $\mathrm{Co}(\mathrm{II}) / \mathrm{NHPI}$ & $70.8-85.8$ & 71 & 132 & 61 & 16.5 \\
$6^{\mathrm{b}}$ & $\mathrm{Co}(\mathrm{II}) / \mathrm{NHPI}$ & $58.2-79.1$ & 59 & 111 & 53 & 16.9 \\
\hline
\end{tabular}

Note: Raw material (described in Table 5) $15 \mathrm{~g}$, Co(acac) 21 wt. $\%$., NHPI 1 wt. $\%, 100{ }^{\circ} \mathrm{C}, 0.5 \mathrm{MPa} \mathrm{O}_{2}, 5 \mathrm{~h}, 1000 \mathrm{rpm}^{\text {a }}$ Co(II) 0.1 wt. $\%$, b air flow $3 \mathrm{~L} / \mathrm{h}, 0.1 \mathrm{MPa}$.

It was found that the oxidation reaction did not proceed without the addition of a catalyst. A slight decrease in the AN, SN, and melting point under non-catalytic reaction conditions (Table 6, Entry 2) indicates thermal degradation of the raw material.

As expected, the system consisting of NHPI and Co(II) showed high catalytic activity, and a significant increase in the AN and SN of the product was achieved. At the same time, however, 
the melting point decreased, which may indicate that products with lower molecular weights were formed by oxygen oxidation.

Unfortunately, the use of cobalt salts as a catalyst adversely affects the color of the product, which may limit its potential applications; therefore, in terms of product quality regarding the color and metal content, it is more beneficial to use only the organocatalyst NHPI.

\subsubsection{Effect of Temperature and Reaction Time}

Oxidation reactions using oxygen were carried out at $90-110{ }^{\circ} \mathrm{C}$ for $2.5,5$, or $7.5 \mathrm{~h}$ in the presence of a catalyst composed of NHPI and Co(II) (Table 7).

Table 7. Effect of temperature and reaction time on the oxidation of the pre-oxidized raw material using oxygen.

\begin{tabular}{|c|c|c|c|c|c|c|c|}
\hline Entry. & $\begin{array}{c}\text { Temperature, } \\
{ }^{\circ} \mathrm{C}\end{array}$ & $\underset{\mathrm{h}}{\mathrm{Time}}$ & $\begin{array}{l}\text { Melting Point, } \\
{ }^{\circ} \mathrm{C}\end{array}$ & $\begin{array}{c}\mathrm{AN}, \\
\mathrm{mgKOH} / \mathrm{g}\end{array}$ & $\begin{array}{c}\mathrm{SN}, \\
\mathrm{mgKOH} / \mathrm{g}\end{array}$ & $\begin{array}{c}\mathrm{EN}, \\
\mathrm{mgKOH} / \mathrm{g}\end{array}$ & $\begin{array}{c}\text { Viscosity at } 120^{\circ} \mathrm{C}, \\
\mathrm{mPa} \cdot \mathrm{s}\end{array}$ \\
\hline 1 & 90 & 5 & $73.6-85.7$ & 65 & 105 & 40 & 17.1 \\
\hline 2 & 100 & 2.5 & $73.7-85.4$ & 70 & 117 & 47 & 16.3 \\
\hline 3 & 100 & 5 & $70.8-85.8$ & 71 & 132 & 61 & 16.5 \\
\hline 4 & 100 & 7.5 & $66.8-76.8$ & 82 & 140 & 58 & 17.0 \\
\hline 5 & 110 & 5 & $68.4-81.8$ & 74 & 132 & 58 & 17.6 \\
\hline
\end{tabular}

Note: raw material (described in Table 5) $15 \mathrm{~g}$, Co(acac) $)_{2} 1 \mathrm{wt} . \%$, NHPI 1 wt. $\%, 0.5 \mathrm{MPa} \mathrm{O}_{2}, 1000 \mathrm{rpm}$.

It was found that with increasing reaction temperature and time, the obtained products were characterized by increasingly higher AN and SN. At the same time, a lower and broader melting point range was obtained, which might indicate product degradation.

\subsubsection{Comparison of $\mathrm{C} 30+$ Olefin Oxidation Products Using $\mathrm{H}_{2} \mathrm{O}_{2}, \mathrm{O}_{2}$, or Both $\mathrm{H}_{2} \mathrm{O}_{2}$ and $\mathrm{O}_{2}$}

The products obtained by two-step oxidation of C30+ olefins using $\mathrm{H}_{2} \mathrm{O}_{2}$ (1st stage; 2 equiv.) and then $\mathrm{O}_{2}$ (2nd stage) as oxidizing agents were compared with products obtained using only $\mathrm{H}_{2} \mathrm{O}_{2}$ (5 equiv.; [28]) or $\mathrm{O}_{2}$. Table 8 presents the degree of oxidation of the products based on the AN and SN.

Table 8. Products of $\mathrm{C} 30+$ olefin oxidation using $\mathrm{H}_{2} \mathrm{O}_{2}, \mathrm{O}_{2}$, or both $\mathrm{H}_{2} \mathrm{O}_{2}$ and $\mathrm{O}_{2}$.

\begin{tabular}{|c|c|c|c|c|c|c|c|}
\hline Entry. & Oxidant & $\begin{array}{l}\text { Amount of } \\
\text { Oxidant }\end{array}$ & $\begin{array}{l}\text { Melting Point, } \\
{ }^{\circ} \mathrm{C}\end{array}$ & $\begin{array}{c}\mathrm{AN}, \\
\mathrm{mgKOH} / \mathrm{g}\end{array}$ & $\begin{array}{c}\mathrm{SN}, \\
\mathrm{mgKOH} / \mathrm{g}\end{array}$ & $\begin{array}{c}\mathrm{EN}, \\
\mathrm{mgKOH} / \mathrm{g}\end{array}$ & $\begin{array}{c}\text { Viscosity at } 120^{\circ} \mathrm{C}, \\
\text { mPa.s }\end{array}$ \\
\hline $1^{a}$ & $\mathrm{H}_{2} \mathrm{O}_{2}$ & 2 equiv. & $78.4-86.4$ & 11 & 19 & 8 & 9.2 \\
\hline $1^{b}$ & $\mathrm{O}_{2}$ & $0.5 \mathrm{MPa}$ & $59.0-68.7$ & 29 & 64 & 35 & 11.3 \\
\hline $2[28]^{c}$ & $\mathrm{H}_{2} \mathrm{O}_{2}$ & 5 equiv. & nd & 59 & 75 & 16 & nd \\
\hline $3^{d}$ & $\mathrm{O}_{2}$ & $0.5 \mathrm{MPa}$ & $55.2-68.4$ & 75 & 135 & 60 & 12.7 \\
\hline
\end{tabular}

a 1st stage: olefins $\mathrm{C} 30+40 \mathrm{~g}, \mathrm{H}_{2} \mathrm{O}_{2} 50 \%, \mathrm{H}_{2} \mathrm{WO}_{4} 0.75$ wt. $\%$, Luviquat 1.5 wt. $\%, \mathrm{H}_{3} \mathrm{PO}_{4} 0.5 \mathrm{M} 0.1 \mathrm{~mL}(0.05 \mathrm{mmol})$, $85{ }^{\circ} \mathrm{C}, 2 \mathrm{~h}, 400 \mathrm{rpm} ;{ }^{\mathrm{b}}$ 2nd stage: product of 1 st stage-15 g; Co(acac) $20.1 \mathrm{wt} . \%$, NHPI $1 \mathrm{wt} . \%, 0.5 \mathrm{MPa} \mathrm{O} 2,100{ }^{\circ} \mathrm{C}, 5$ h, $1000 \mathrm{rpm}$; ${ }^{\mathrm{c}}$ Olefins $\mathrm{C} 30+40 \mathrm{~g}, \mathrm{H}_{2} \mathrm{O}_{2} 50 \%, \mathrm{H}_{2} \mathrm{WO}_{4} 1.5 \mathrm{wt} . \%$, Luviquat $5.0 \mathrm{wt} . \%, \mathrm{H}_{2} \mathrm{SO}_{4} 1 \mathrm{M} 17 \mu \mathrm{mol} / \mathrm{g}, 90{ }^{\circ} \mathrm{C}, 10 \mathrm{~h}$, $500 \mathrm{rpm}$ [28]; ${ }^{\mathrm{d}}$ Olefins C $30+15 \mathrm{~g}$, Co(acac) 20.1 wt. $\%$, NHPI 1 wt. $\%, 0.5 \mathrm{MPa} \mathrm{O}_{2}, 100{ }^{\circ} \mathrm{C}, 5 \mathrm{~h}, 1000 \mathrm{rpm}$.

Products with high oxidation degrees were obtained by oxidizing C30+ using only $\mathrm{H}_{2} \mathrm{O}_{2}$ (Table 8, Entry 2) or $\mathrm{O}_{2}$ (Table 8, Entry 3), as well as both oxidants (Entry 1). The composition of these products were compared using GC-MS (Figures 3-5; after esterification with methanol to form volatile methyl esters) and FT-IR (Figure 6). 


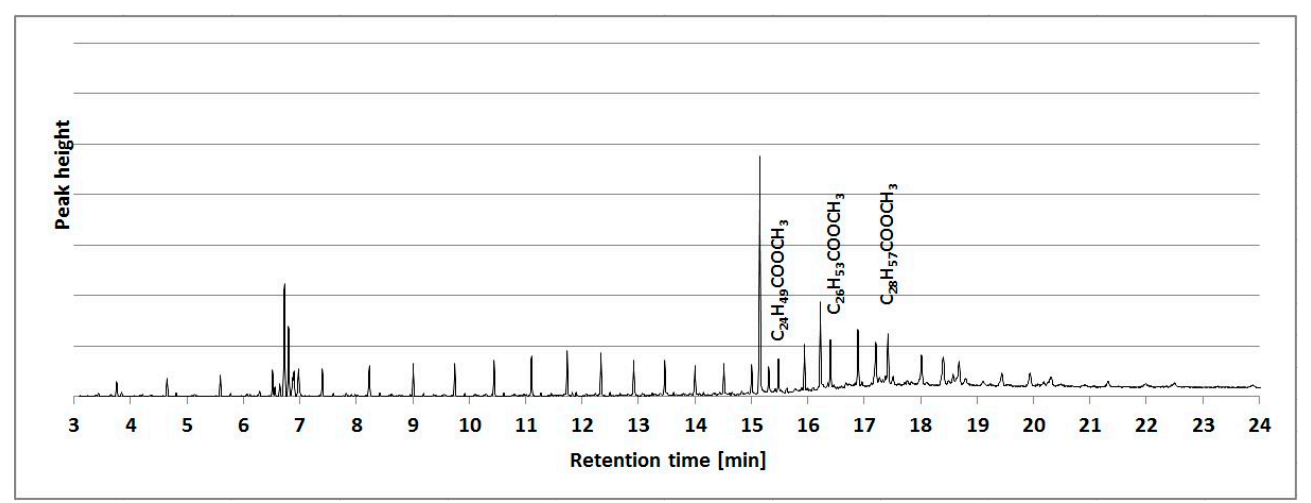

Figure 3. GC-MS chromatogram of product obtained by C30+ olefin oxidation with $\mathrm{O}_{2}$ (Table 8, Entry 3; mass spectra Figures S9-S12).

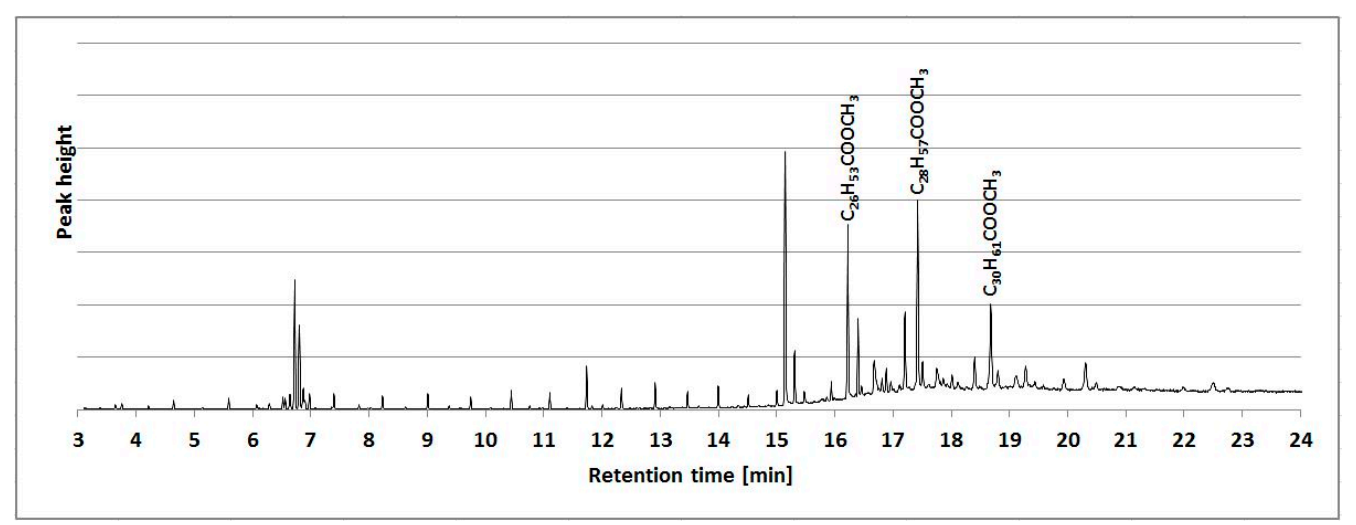

Figure 4. GC-MS chromatogram of product obtained by C30+ olefin oxidation using 2 equiv. of $\mathrm{H}_{2} \mathrm{O}_{2}$ (Table 8, Entry 1a; mass spectra Figures S9-S12).

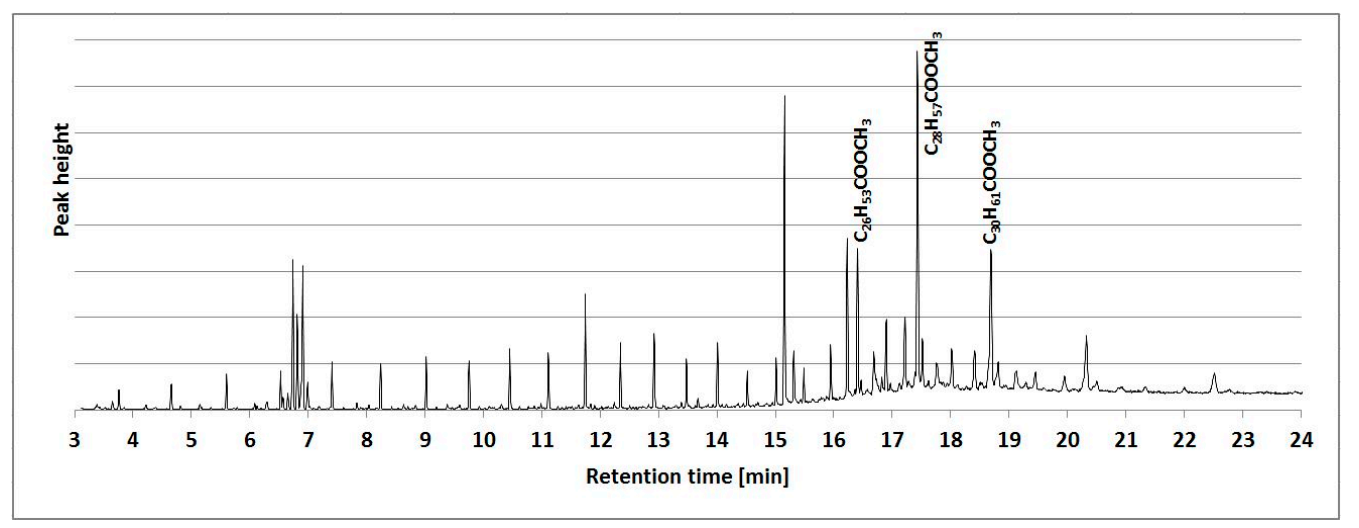

Figure 5. GC-MS chromatogram of product obtained by $\mathrm{C} 30+$ olefin oxidation using $\mathrm{H}_{2} \mathrm{O}_{2}$ and $\mathrm{O}_{2}$ (Table 8, Entry 1b; mass spectra Figures S9-S12). 


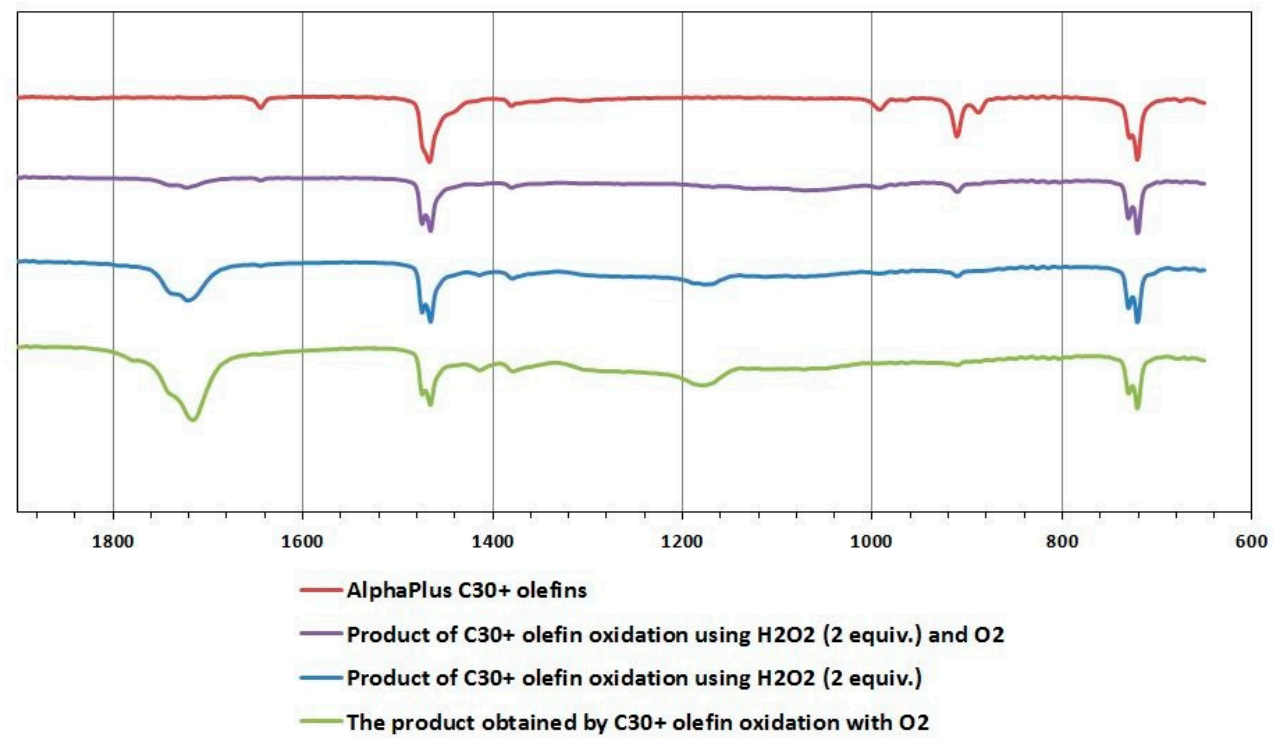

Figure 6. Comparison of FT-IR spectra of oxidation products.

According to the authors [28], the oxidation product obtained using 5 equiv. of hydrogen peroxide contained carboxylic acids with an odd number of carbon atoms (mostly C27 to C39). The main component was carboxylic acid $\mathrm{C}_{28} \mathrm{H}_{57} \mathrm{COOH}$, which formed due to oxidative cleavage of $\mathrm{C}_{30} \mathrm{H}_{60}$ $\alpha$-olefin. They observed only small amounts of short-chain carboxylic acid.

In contrast, the product obtained by oxidation using only oxygen contained acids with even and odd numbers of carbons atoms and more components with lower volatility (number of carbon atoms $<25$ ) (Figure 3; Table 8, Entry 3). This is the effect of free-radical oxidation in which generated peroxy radicals may have abstracted hydrogens from alkyl chain or added to double bonds. Hydrogen abstraction may lead to alkyl chain degradation and the formation of low-molecular-weight products.

Chromatograms of products obtained by the 2-stage method are presented in Figures 4 and 5 (Table 8, Entry 1). The results show that during the second stage of oxidation using $\mathrm{O}_{2}$, the amount of $\mathrm{C}_{28} \mathrm{H}_{57} \mathrm{COOH}$ increased, which confirmed that oxygen partially replaced $\mathrm{H}_{2} \mathrm{O}_{2}$ during the oxidative cleavage of alkenes. Compounds formed during the first steps of oxidation using $\mathrm{H}_{2} \mathrm{O}_{2}$, e.g., diols, may be oxidized to the respective acids via carbon-carbon bond cleavage; however, compared with the product obtained by one-stage oxidation using 5 equiv. of $\mathrm{H}_{2} \mathrm{O}_{2}$, a larger amount of acids with carbon numbers below 25 were obtained, both with even and odd numbers. This was a result of the abovementioned free-radical oxygen oxidation.

Figure 6 compares the FT-IR spectra of raw materials and products obtained by the two-step method, after the 1st stage of oxidation using 2 equiv. of $\mathrm{H}_{2} \mathrm{O}_{2}$ and the 2nd stage using $\mathrm{O}_{2}$. In the spectra of both oxidation products, no $\mathrm{C}=\mathrm{C}$ band $\left(1640 \mathrm{~cm}^{-1}\right.$, stretching vibration) was observed, while bands at $1720 \mathrm{~cm}^{-1}$ due to carbonyl groups $(\mathrm{C}=\mathrm{O})$ appeared.

\section{Conclusions}

Studies on the two-step oxidation of long-chain terminal olefins using environmentally-friendly oxidants $\mathrm{H}_{2} \mathrm{O}_{2}$ and $\mathrm{O}_{2}$ were performed. In the first stage, $\mathrm{C} 30+$ olefins were oxidized using $\mathrm{H}_{2} \mathrm{O}_{2}$. It was established that to obtain a product with a low double bond content, it was beneficial to carry out the reaction using 2 equiv. of $\mathrm{H}_{2} \mathrm{O}_{2}$ in the presence of $0.75 \mathrm{wt} . \% \mathrm{H}_{2} \mathrm{WO}_{4}, 1.5 \mathrm{wt}$.\% Luviquat, $0.1 \mathrm{~mL}$ $0.5 \mathrm{M} \mathrm{H}_{2} \mathrm{SO}_{4}$, for $1-2 \mathrm{~h}$ at $85{ }^{\circ} \mathrm{C}$. The use of 1 equiv. of $\mathrm{H}_{2} \mathrm{O}_{2}$-according to the reaction stoichiometry sufficient for complete epoxidation of the alkene-resulted in the incomplete conversion of alkenes. This was due to the consumption of hydrogen peroxide in the subsequent oxidation reactions, as well as its partial decomposition. A product with an acid number of 11 and a saponification number of 19 was obtained. 
Further oxidation of this product was conducted in the presence of a catalytic system composed of NHPI and Co(II) under a pressurized oxygen atmosphere. The results showed that during the process, the acid and ester contents increased, and a product with an acid number of 29 and a saponification number of 64 was obtained.

A comparison of the product's composition obtained after the 1st and 2nd reaction stages using GC-MS showed that $\mathrm{H}_{2} \mathrm{O}_{2}$ could be partially replaced by oxygen in oxidative cleavage of long chain $\alpha$-olefins. It was demonstrated that the content of acids formed by the oxidative cleavage of alkenes increased in the second stage; however, the use of oxygen led to the formation of larger amounts of less-volatile compounds due to alkyl chain degradation.

Supplementary Materials: The following are available online at http://www.mdpi.com/1996-1944/13/20/4545/s1, Figures S1-S8: Mass spectra of olefins identified in starting material, Figures S9-S12: Mass spectra of esters identified in oxidation products.

Author Contributions: Conceptualization, B.O.; methodology, B.O.; investigation, K.P.-oxidation processes using $\mathrm{H}_{2} \mathrm{O}_{2}$ and both $\mathrm{H}_{2} \mathrm{O}_{2} / \mathrm{O}_{2}$ and D.L.- oxidation processes using $\mathrm{O}_{2}$ and GC-MS analysis and G.T.- ${ }^{1} \mathrm{H}$ NMR analysis; writing — original draft preparation, B.O. and G.T. and K.P.; supervision, B.O. All authors have read and agreed to the published version of the manuscript.

Funding: This research was funded by National Centre for Research and Development of Poland, grant number TANGO3/434594/NCBR/2019.

Conflicts of Interest: The authors declare no conflict of interest.

\section{References}

1. Spannring, P.; Bruijnincx, P.C.A.; Weckhuysen, B.M.; Gebbink, R.J.M.K. Transition Metal-Catalyzed Oxidative Double Bond Cleavage of Simple and Bio-Derived Alkenes and Unsaturated Fatty Acids. Catal. Sci. Technol. 2014, 4, 2182-2209. [CrossRef]

2. Ogino, T.; Mochizuki, K. Homogeneous Permanganate Oxidation in Non-Aqueous Organic Solution. Selective Oxidations of Olefins Into 1,2-Diols or Aldehydes. Chem. Lett. 1979, 8, 443-446. [CrossRef]

3. Wiberg, K.; Saegebarth, K. The Mechanisms of Permanganate Oxidation. IV. Related Reactions. J. Am. Chem. Soc. 1957, 79, 2822-2824. [CrossRef]

4. Freeman, F.; Yamachika, N.J. Chromyl Chloride Oxidations. IV. Kinetics and Mechanism of the Addition to Styrene. J. Am. Chem. Soc. 1970, 92, 3730-3733. [CrossRef]

5. Berkowitz, L.M.; Rylander, P.N. Use of Ruthenium Tetroxide as a Multi-Purpose Oxidant. J. Am. Chem. Soc. 1958, 80, 6682-6684. [CrossRef]

6. Pappo, R.; Allen, D.S.; Johnson, W.S.; Lemieux, R.U. Osmium Tetroxide-Catalyzed Periodate Oxidation of Olefinic Bonds. J. Org. Chem. 1956, 21, 478-479. [CrossRef]

7. Ashford, S.W.; Grega, K.C. Oxidative Cleavage of 1,3-Dicarbonyls to Carboxylic Acids with Oxone. J. Org. Chem. 2001, 66, 1523-1524. [CrossRef]

8. Moorthy, J.N.; Parida, K.N. Oxidative Cleavage of Olefins by In Situ-Generated Catalytic 3,4,5,6Tetramethyl-2-Iodoxybenzoic Acid/Oxone. J. Org. Chem. 2014, 79, 11431-11439. [CrossRef]

9. Mi, C.; Li, L.; Meng, X.G.; Yang, R.Q.; Liao, X.H. Highly Selective Oxidation of Unsaturated Hydrocarbons to Carbonyl Compounds by Two-Phase Catalysis. Tetrahedron 2016, 72, 6705-6710. [CrossRef]

10. Singh, F.V.; Milagre, H.M.S.; Eberlin, M.N.; Stefani, H.A. Synthesis of Benzophenones from Geminal Biaryl Ethenes Using $m$-Chloroperbenzoic Acid. Tetrahedron Lett. 2009, 50, 2312-2316. [CrossRef]

11. Hossain, M.M.; Huang, W.K.; Chen, H.J.; Wang, P.H.; Shyu, S.G. Efficient and Selective Copper-Catalyzed Organic Solvent-Free and Biphasic Oxidation of Aromatic Gem-Disubstituted Alkenes to Carbonyl Compounds by tert-Butyl Hydroperoxide at Room Temperature. Green Chem. 2014, 16, 3013-3017. [CrossRef]

12. Ha, Y.; Mu, M.; Liu, Q.; Ji, N.; Song, C.; Ma, D. Mn-MIL-100 Heterogeneous Catalyst for the Selective Oxidative Cleavage of Alkenes to Aldehydes. Catal. Commun. 2018, 103, 51-55. [CrossRef]

13. Shaikh, T.M.; Hong, F.E. Iron-Catalyzed Oxidative Cleavage of Olefins and Alkynes to Carboxylic Acids with Aqueous tert-Butyl Hydroperoxide. Adv. Synth. Catal. 2011, 353, 1491-1496. [CrossRef]

14. Xing, D.; Guan, B.; Cai, G.; Fang, Z.; Yang, L.; Shi, Z. Gold(I)-Catalyzed Oxidative Cleavage of a C-C Double Bond in Water. Org. Lett. 2006, 8, 693-696. [CrossRef] 
15. Ranu, B.C.; Bhadra, S.; Adak, L. Indium(III) Chloride-Catalyzed Oxidative Cleavage of Carbon-Carbon Multiple Bonds by tert-Butyl Hydroperoxide in Water-A Safer Alternative to Ozonolysis. Tetrahedron Lett. 2008, 49, 2588-2591. [CrossRef]

16. Diaper, D.G.M. Ozonolysis of 1-substituted cycloolefins. Can. J. Chem. 1955, 33, 1720-1723. [CrossRef]

17. Zaldman, B.; Kisilev, A.; Sasson, Y.; Garti, N. Double Bond Oxidation of Unsaturated Fatty Acids. J. Am. Oil Chem. Soc. 1988, 65, 611-615. [CrossRef]

18. Wang, M.; Ma, J.; Liu, H.; Luo, N.; Zhao, Z.; Wang, F. Sustainable Productions of Organic Acids and Their Derivatives from Biomass via Selective Oxidative Cleavage of C-C Bond. ACS Catal. 2018, 8, 2129-2165. [CrossRef]

19. Urgoitia, G.; SanMartin, R.; Herrero, M.T.; Domínguez, E. Aerobic Cleavage of Alkenes and Alkynes into Carbonyl and Carboxyl Compounds. ACS Catal. 2017, 7, 3050-3060. [CrossRef]

20. Wang, A.; Jiang, H. Palladium-Catalyzed Direct Oxidation of Alkenes with Molecular Oxygen: General and Practical Methods for the Preparation of 1,2-Diols. J. Org. Chem. 2010, 75, 2321-2326. [CrossRef]

21. Herrmann, W.A.; Weskamp, T.; Zoller, J.P.; Fischer, R.W. Methyltrioxorhenium: Oxidative Cleavage of CC-Double Bonds and Its Application in a Highly Efficient Synthesis of Vanillin from Biological Waste. J. Mol. Catal. A Chem. 2000, 153, 49-52. [CrossRef]

22. Nourian, M.; Zadehahmadi, F.; Kardanpour, R.; Tangestaninejad, S.; Moghadam, M.; Mirhhani, V.; Mohammadpoor-Baltork, I. Highly Efficient Oxidative Cleavage of Alkenes and Cyanosilylation of Aldehydes Catalysed by Magnetically Recoverable MIL-101. Appl. Organomet. Chem. 2018, 32, e3957. [CrossRef]

23. Antonelli, E.; Aloisio, R.D.; Gambaro, M.; Fiorani, T.; Venturello, C. Efficient Oxidative Cleavage of Olefins to Carboxylic Acids with Hydrogen Peroxide Catalyzed by Methyltrioctylammonium Tetrakis(Oxodiperoxotungsto) Phosphate(3-) under Two-Phase Conditions. Synthetic Aspects and Investigation of the Reaction Cours. J. Org. Chem. 1998, 63, 7190-7206. [CrossRef] [PubMed]

24. Noyori, R.; Aoki, M.; Sato, K.; Noyori, R. Green Oxidation with Aqueous Hydrogen Peroxide. Chem. Commun. 2003, 1977-1986. [CrossRef] [PubMed]

25. Ishii, Y.; Yamawaki, K.; Ura, T.; Yamada, H.; Yoshida, T.; Ogawa, M. Hydrogen Peroxide Oxidation Catalyzed by Heteropoly Acids Combined with Cetylpyridinium Chloride: Epoxidation of Olefins and Allylic Alcohols, Ketonization of Alcohols and Diols, and Oxidative Cleavage of 1,2-Diols and Olefins. J. Org. Chem. 1988, 53, 3587-3593. [CrossRef]

26. Pai, Z.P.; Selivanova, N.V.; Oleneva, P.V.; Berdnikova, P.V.; Beskopyl'nyi, A.M. Catalytic Oxidation of $\alpha$ -Alkenes with Hydrogen Peroxide to Carboxylic Acids in the Presence of Peroxopolyoxotungstate Complexes. Catal. Commun. 2017, 88, 45-49. [CrossRef]

27. Kadyrov, R.; Hackenberger, D. Oxidative Cleavage of Long Chain Olefins to Carboxylic Acids with Hydrogen Peroxide. Top. Catal. 2014, 57, 1366-1371. [CrossRef]

28. Pyszny, D.; Piotrowski, T.; Orlińska, B. Oxidative Cleavage of Long-Chain Terminal Alkenes to Carboxylic Acids. Org. Process Res. Dev. 2019, 23, 309-319. [CrossRef]

29. Wang, T.; Jing, X.; Chen, C.; Yu, L. Organoselenium-Catalyzed Oxidative C=C Bond Cleavage: A Relatively Green Oxidation of Alkenes into Carbonyl Compounds with Hydrogen Peroxide. J. Org. Chem. 2017, 82, 9342-9349. [CrossRef]

30. Chiappe, C.; Sanzone, A.; Dyson, P.J. Styrene Oxidation by Hydrogen Peroxide in Ionic Liquids: The Role of the Solvent on the Competition between Two Pd-Catalyzed Processes, Oxidation and Dimerization. Green Chem. 2011, 13, 1437-1441. [CrossRef]

31. Behr, A.; Tenhumberg, N.; Wintzer, A. Efficient Ruthenium-Catalysed Oxidative Cleavage of Methyl Oleate with Hydrogen Peroxide as Oxidant. RSC Adv. 2013, 3, 172-180. [CrossRef]

32. Pai, Z.P.; Tolstikov, A.G.; Berdnikova, P.V.; Kustova, G.N.; Khlebnikova, T.B.; Selivanova, N.V.; Shangina, A.B.; Kostrovskii, V.G. Catalytic Oxidation of Olefins and Alcohols with Hydrogen Peroxide in a Two Phase System Giving Mono- and Dicarboxylic Acids. Russ. Chem. Bull. 2005, 54, 1847-1854. [CrossRef]

33. Sato, K.; Aoki, M.; Noyori, R. A “Green" Route to Adipic Acid: Direct Oxidation of Cyclohexenes with 30 Percent Hydrogen Peroxide Onset of Catalytic Activity of Gold Clusters on Titania with the Appearance of Nonmetallic Properties. Science 1998, 281, 1646-1648. [CrossRef]

34. Wen, Y.; Wang, X.; Wei, H.; Li, B.; Jin, P.; Li, L. A Large-Scale Continuous- Flow Process for the Production of Adipic Acid via Catalytic Oxidation of Cyclohexene with H2O2. Green Chem. 2012, 14, 2868-2875. [CrossRef] 
35. Benessere, V.; Cucciolito, M.E.; De Santis, A.; Di Serio, M.; Esposito, R.; Ruffo, F.; Turco, R. Sustainable Process for Production of Azelaic Acid through Oxidative Cleavage of Oleic Acid. J. Am. Oil Chem. Soc. 2015, 92, 1701-1707. [CrossRef]

36. Godard, A.; De Caro, P.; Thiebaud-Roux, S.; Vedrenne, E.; Mouloungui, Z. New Environmentally Friendly Oxidative Scission of Oleic Acid into Azelaic Acid and Pelargonic Acid. J. Am. Oil Chem. Soc. 2013, 90, 133-140. [CrossRef]

37. Yoshimura, Y.; Ogasawara, Y.; Suzuki, K.; Yamaguchi, K.; Mizuno, N. “Release and Catch" Catalysis by Tungstate Species for the Oxidative Cleavage of Olefins. Catal. Sci. Technol. 2017, 7, 1662-1670. [CrossRef]

38. Santacesaria, E.; Sorrentino, A.; Rainone, F.; Di Serio, M.; Speranza, F. Oxidative Cleavage of the Double Bond of Monoenic Fatty Chains in Two Steps: A New Promising Route to Azelaic Acid and Other Industrial Products. Ind. Eng. Chem. Res. 2000, 39, 2766-2771. [CrossRef]

39. Santacesaria, E.; Ambrosio, M.; Sorrentino, A.; Tesser, R.; Di Serio, M. Double Bond Oxidative Cleavage of Monoenic Fatty Chains. Catal. Today 2003, 79-80, 59-65. [CrossRef]

40. Oakley, M.A.; Woodward, S.; Coupland, K.; Parker, D.; Temple-Heald, C. Practical Dihydroxylation and C-C Cleavage of Unsaturated Fatty Acids. J. Mol. Catal. A Chem. 1999, 150, 105-111. [CrossRef]

41. Pyszny, D.; Orlińska, B. Solvent-Free Aerobic Oxidative Cleavage of Alkenes Catalyzed by N-Hydroxyphthalimide. React. Kinet. Mech. Catal. 2018, 124, 123-138. [CrossRef]

(C) 2020 by the authors. Licensee MDPI, Basel, Switzerland. This article is an open access article distributed under the terms and conditions of the Creative Commons Attribution (CC BY) license (http://creativecommons.org/licenses/by/4.0/). 